\title{
Different effects of planktonic invertebrate predators and fish on the plankton community in experimental mesocosms
}

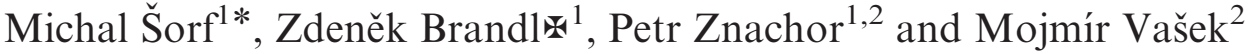 \\ 1 Faculty of Science, University of South Bohemia, Branišovská 31, CZ-370 05, České Budějovice, Czech Republic \\ 2 Institute of Hydrobiology, Biology Centre of the Academy of Sciences of the Czech Republic, Na Sádkách 7, CZ-370 05, \\ České Budějovice, Czech Republic
}

Received 26 June 2013; Accepted 24 December 2013

\begin{abstract}
The impact of fish and cyclopoid copepod predation on zooplankton communities was evaluated using large-volume mesocosms (depth $9.5 \mathrm{~m}$; volume $13 \mathrm{~m}^{3}$ ) in the Ŕimov reservoir (Czech Republic). Two yearling roach and perch individuals introduced into mesocosms represented the fish treatment, which was compared to cyclopoid copepods (initial abundance of 2 ind. $\mathrm{L}^{-1}$ ) and a control with no initial addition of predators. Our results clearly support the hypothesis that planktivorous fish feeding leads to the suppression of large-bodied cladocerans. In the presence of fish, the cladoceran community changed from a dominance of large-bodied Daphnia spp. at the beginning to dominance by the smaller Bosmina longirostris at the end of the experiment. Chlorophyll-a concentration and rotifer abundances increased in the absence of daphnids. In the absence of fish, the presence of large-bodied cladocerans resulted in decreasing chlorophyll-a concentration. Although no significant differences were observed between cyclopoid abundances in treatments stocked with cyclopoids and the control, the proportion of large cladocerans clearly showed the effect of the manipulation. The similar trends in both of these treatments did not confirm the importance of cyclopoid predation in our experiment. The overall strong effect of fish over cyclopoid predation suggests the main role of fish predation in the forming of zooplankton communities and in turn impacting phytoplankton biomass in mesocosms.
\end{abstract}

Key words: predation / zooplankton / perch / roach / mesocosms

\section{Introduction}

Predation is one of the important factors determining food webs in the aquatic environment. The combination of vertebrate and invertebrate predation forms zooplankton assemblages in natural lakes (Blumenshine and Hambright, 2003) as well as in reservoirs (Hansson et al., 1998). There are great differences between the effect of fish and that of invertebrate predators (IP) on zooplankton species composition, biomass and size structure (e.g., Wojtal et al., 2004 or Manca et al., 2008). The reason for such dissimilarities lies in the different way they find and obtain suitable prey. Although most zooplanktivorous fish (and predatory cladocerans) forage visually (Werner and Hall, 1974), planktonic IP, such as cyclopoid copepods, look for food by means of mechanoreceptors and/or chemoreceptors (Dussart and Defaye, 2001). Generally, the encounter rate increases with prey body size. Large prey is more visible and therefore more susceptible to

*Corresponding author: michal . sorf@prf.jcu.cz

Deceased visually foraging predators. Furthermore, planktivorous fish benefit from feeding on larger prey which exceeds the energy cost for foraging (Persson and Greenberg, 1990). Unlike fish, planktonic predators such as cyclopoid copepods or predatory cladocerans cannot consume the whole prey, but tear the prey into parts. Hence, feeding on small or medium-sized prey seems to be more effective for IP, as predicted by the optimal foraging theory (Werner and Hall, 1974).

The structuring role of fish on zooplankton assemblage has been revealed by many authors since the 1960s. The early observations of the dramatic impact of fish on zooplankton abundance and size structure (e.g., Hrbáček and Hrbáčková-Esslová, 1960; Hrbáček et al., 1961; Hrbáček, 1962) resulted in the postulation of the size-efficiency hypothesis (Brooks and Dodson, 1965), which greatly influenced further studies on predator-prey interactions. Afterwards, recognition of subsequent effects of fish predation on lower levels of freshwater food webs led to the concept of cascading trophic interactions (Carpenter et al., 1985; see also the review by Brett and Goldman, 1996). This concept suggests that the promotion of efficient 
planktonic herbivores through decreased biomass of planktivores by piscivores can reduce the biomass of phytoplankton. This general pattern can be modified by altered life histories or other interactions among particular species such as defence mechanisms in prey (Jeffries, 1988; Kolar and Wahl, 1998; Straile and Halbich, 2000). These findings are widely used during food web manipulation with the ultimate goal to improve water quality management (i.e., biomanipulation techniques) (Berg et al., 1997; Beklioglu, 1999; Ha et al., 2013).

Although the role of fish in aquatic food webs is widely accepted, the effect of planktonic IP on lower trophic levels might be even higher than that of fish (e.g., Blumenshine and Hambright, 2003). Benndorf et al. (2000) reported high abundance of IP when planktivorous fish were reduced in numbers by very strong pressure from piscivorous fish. Increasing water turbidity also gives preference to IP over fish (Horppila and Liljendahl-Nurminen, 2005). On the contrary, Hansson and Tranvik (1996) concluded that IP have only a marginal effect compared with vertebrate predation pressure on zooplankton. The statement of Carpenter and Kitchell (1992) that a "rigorous re-examination of accumulated results is beneficial" seems to be valid even after 20 years.

In this study, large-volume mesocosms were employed in a manipulation experiment aimed at evaluating the separate effects of vertebrate and invertebrate predation in a man-made lake. The scope of the experimental manipulation lies in the evaluation of the separate effects of vertebrate and planktonic IP on a plankton community.

The pelagic zone of the meso-eutrophic Rímov reservoir (Czech Republic) was simulated in the field mesocosm experiment where top predators of zooplankton were manipulated. Besides predatory cladocerans Leptodora kindtii, which occur lately in the season, and Polyphemus pediculus inhabiting inshore habitats, cyclopoid copepods are the most abundant IP in the reservoir (Devetter and Sed'a, 2006) though their impact on zooplankton assemblage compared to fish predation is largely unknown.

Based on the above mentioned facts on differences between fish and invertebrate predation, and given the situation in the Rímov reservoir, we hypothesised that (a) IP (cyclopoid copepods) would prominently affect both rotifers and smaller cladocerans in terms of their abundances; (b) fish predation, eliminating larger cladocerans, would increase phytoplankton biomass and (c) phytoplankton would facilitate the increase in rotifer abundance by providing available food resources and exemplifying the cascade effect in aquatic trophic food web.

\section{Materials and Methods}

\section{Experimental setup and treatment description}

The field experiment was conducted in the mesoeutrophic canyon-shaped Římov reservoir $\left(48^{\circ} 50^{\prime} \mathrm{N}\right.$, $14^{\circ} 29^{\prime} \mathrm{E}$; South Bohemia, Czech Republic) in May and June 2008. The Rímov reservoir has a surface area of
$2.1 \mathrm{~km}^{2}$, the mean theoretical retention time is 95 days. Two floating metal constructions with dimensions of $3.4 \times 3.4 \mathrm{~m}^{2}$ were assembled near the dam, where the maximum depth is $45 \mathrm{~m}$. The supporting construction was fixed in each corner on polystyrene floats and anchored to the bottom by concrete blocks. Both constructions carried altogether eight transparent polyethylene bags (diameter of $1.5 \mathrm{~m}$ and length of $9.5 \mathrm{~m}$ ). The enclosed volume of water was $13 \mathrm{~m}^{3}$. Metal rings clipped from the outside on the top and above the bottom of each bag allowed in maintaining a regular cylindrical shape for each mesocosm. The top of the mesocosms was not covered and remained approximately $0.4 \mathrm{~m}$ above the surface to prevent inflow of reservoir water by wave action. At the bottom, the bags were tightly closed and thus water exchange between the inner and outer environments was eliminated. Šorf et al. (2013) provided the detailed description of the mesocosm design.

The mesocosms were filled with reservoir water filtered through $100 \mu \mathrm{m}$ mesh. Water was pumped into the mesocosms a week before the beginning of the experiment. Two days were needed to fill all the polyethylene bags using a petrol pump. Zooplankton was collected from the reservoir by vertical hauls from 0 to $10 \mathrm{~m}$ and $710-1000 \mu \mathrm{m}$ fraction consisted mainly of larger cladoceran Daphnia spp. was sorted on a mesh and after thorough mixing added to all mesocosms. Initial daphnid density in the mesocosms was set at 4 ind. $\mathrm{L}^{-1}$. At the time of filling, daphnid density in the reservoir reached almost 20 ind. $\mathrm{L}^{-1}$ on 12th May 2008, the first day of the experiment. Triplicated treatments were established to evaluate the effect of vertebrate predators (VP) and IP. In addition, two duplicated mesocosms were left as controls with no extra addition of predators (NP). An unbalanced design with triplicated treatments and duplicated controls is the result of trade-off between the number of supporting constructions and the manpower needed to perform the experiment (Šorf et al., 2013). The vertebrate treatment was composed of two roach (Rutilus rutilus) and two perch (Perca fluviatilis) of the year-class 2007. All yearling fish were seined in the Rímov reservoir where both juvenile roach and perch are known to feed mainly on microcrustaceans (Peterka and Matěna, 2009). Initial standard lengths were $90.8 \pm 7.4 \mathrm{~mm}$ for roach and $75.8 \pm 7.4 \mathrm{~mm}$ for perch. Fish lengths were converted to biomass using length-weight regressions obtained for juvenile roach and perch in the Rímov reservoir (M. Vašek, unpublished data). The experimental biomass of roach reached $147 \mathrm{~kg} \cdot \mathrm{ha}^{-1}$ whereas that of perch was $83 \mathrm{~kg} \cdot \mathrm{ha}^{-1}$ at the beginning of the experiment. At the end of the experiment, the fish were caught alive, with the exception of one lost roach, whose remains were recorded. The IP treatment contained planktonic IP, mainly the cyclopoid copepods Cyclops vicinus Uljanin and Mesocyclops leuckarti Claus in initial densities of about 2 ind. $\mathrm{L}^{-1}$ corresponding to the reservoir density of copepods. Invertebrate predators were collected in the same way as daphnids, sorted on a $620 \mu \mathrm{m}$ mesh and separated from cladocerans using a few drops of narcotising agent (chloroform and ethanol 1:10), which immobilises cladocerans, but has just 
a weak effect on cyclopoids (Straškraba, 1964). During the procedure, an injection of numerous small air bubbles into the vessel with the mixture of cladocerans and copepods caused the air bubbles to be trapped between the cladoceran carapaces. After few minutes, the daphnids remained at the water surface whereas the cyclopoids freely swam in the water column. Besides cyclopoids, the predatory cladocerans $L$. kindtii and P. pediculus occurred in the mesocosms during the experiment.

Both the VP and IP were added on 12th May. A 3-day period between addition of the organisms and the first sampling served as an acclimation period, when temperature stratification and distribution of organisms in the bags developed. A 5-week experimental period was used with respect to the generation time of planktonic populations. At $20^{\circ} \mathrm{C}$, the generation time of Daphnia galeata ranges from 6 to 15 days depending on food availability (Hrbáčková, 1974), whereas phytoplankton and rotifer generation times are generally much shorter (Reynolds, 2006; Wallace et al., 2006).

\section{Sampling and laboratory analysis}

Seven regular samplings were made at 6-day intervals in the period from 16th May and to 21st June 2008. A Van Dorn sampler of $1 \mathrm{~m}$ length and $6.5 \mathrm{~L}$ volume was used for zooplankton collection. We sampled the whole water column in every mesocosm at $1 \mathrm{~m}$ intervals and an integrated sample was filtered through $40 \mu \mathrm{m}$ mesh size. The samples were preserved in $4 \%$ formaldehyde solution. Zooplankton samples were determined and counted in an open Sedgwick-Rafter chamber (Edmonson, 1971). Vertical temperature and dissolved oxygen profiles, along with surface values of $\mathrm{pH}$ and conductivity, were measured using a multiparameter WTW Multi 340i probe (WTW, Germany). Additionally, water transparency was measured with a Secchi disc.

A multi-wavelength submersible fluorescence probe (FluoroProbe, bbe-Moldaenke, Kiel, Germany) with temperature sensor was employed to measure temperature and chlorophyll-a concentration in a detailed vertical profile at $\sim 0.2 \mathrm{~m}$ intervals down to the bottom of the experimental mesocosms. According to the specific fluorescence spectra of distinct groups of phytoplankton, the probe permits differentiation of cyanobacteria, chromophytes + dinoflagellates (a mixed group with diatoms being frequently the most important), cryptophytes and chlorophytes in mixed natural populations (Beutler et al., 2002). The fluorescence probe was provided with original software (FluoroProbe 1.8.4, bbe Moldaence), which allowed for quantification of each phytoplankton group expressed as a mean value for the whole water column in the mesocosms.

\section{Statistical analysis}

The effects of vertebrate and invertebrate predation were tested by one-way repeated measures ANOVA with the post hoc Tukey Unequal N HSD test. The two-sided Dunnett test was used when direct comparison with the control was applied (e.g., for proportion of Daphnia spp. in cladoceran community). The unequal test was applied because the treatments were in triplicates, whereas the control was only duplicated. Due to differences from normality, data on zooplankton and phytoplankton were $\log (\mathrm{x}+1)$ transformed. Two-way repeated measures ANOVA was used for testing the differences in the vertical temperature and dissolved oxygen profiles with time and depth as categorical factors. Comparison of fish biomass was done by paired $t$-test. All statistical analyses were run using Statistica 6.0 (StatSoft Inc., USA).

\section{Results}

\section{Abiotic factors}

Thermal stratification was established soon after the beginning of the experiment and lasted through its course with the overall mean of surface water temperature across all mesocosms of $19.92 \pm 2.48^{\circ} \mathrm{C}$ (mean $\pm \mathrm{SD}$ ). Temperature profiles significantly differed over time $(F=5349$; d.f. $=6 ; P<0.001)$, but not among treatments $(F=1$; d.f. $=12 ; P=0.7)$. Contrary to temperature, dissolved oxygen concentration significantly changed not only over time $(F=1161$; d.f. $=6 ; P<0.001)$ but even among treatments $(F=5.7$; d.f. $=12 ; P<0.001)$. The timeweighted averages of the dissolved oxygen concentration measured near to the water surface were as follows: $11.4 \pm 0.1 \mathrm{mg} . \mathrm{L}^{-1}$ in $\mathrm{VP}, 11.6 \pm 0.1 \mathrm{mg} . \mathrm{L}^{-1}$ in IP and $10.8 \pm 0.8 \mathrm{mg} . \mathrm{L}^{-1}$ in no predation (NP). Neither $\mathrm{pH}$ nor conductivity differed significantly among treatments. Transparency measured as Secchi depth was greatly affected by the presence or absence of fish $(F=20.93$; d.f. $=2 ; P<0.01)$. Transparency was highest in the control at the end of the experiment (VP: $2.4 \pm 0.25 \mathrm{~m}$, IP: $3.2 \pm 1.1 \mathrm{~m}$ and NP: $4.45 \pm 0.6 \mathrm{~m}$; Fig. 1 ).

\section{Phyto- and zooplankton}

At the beginning of the experiment, the depthintegrated mean concentration of chlorophyll-a was $\sim 1 \mu \mathrm{g} . \mathrm{L}^{-1}$ in all treatments and the reservoir. Later, chlorophyll-a gradually increased particularly in the VP treatment attaining $7.5 \mu \mathrm{g} . \mathrm{L}^{-1}$ at the end of the experiment (Fig. 2A). An increasing but less prominent trend was found in the IP treatment whereas no significant change was observed in the control. Both effects of treatment and time were significant for all major phytoplankton groups (Fig. 2). The effect of fish predation on phytoplankton was significantly different from that of invertebrate predation and the control. Fish predation supported mainly chlorophytes, cryptophytes and chromophytes/dinophytes (Fig. 2B-D). Cyanobacteria were far less abundant and their biomass slightly increased at the end of the experiment in all treatments (Fig. 2E). 


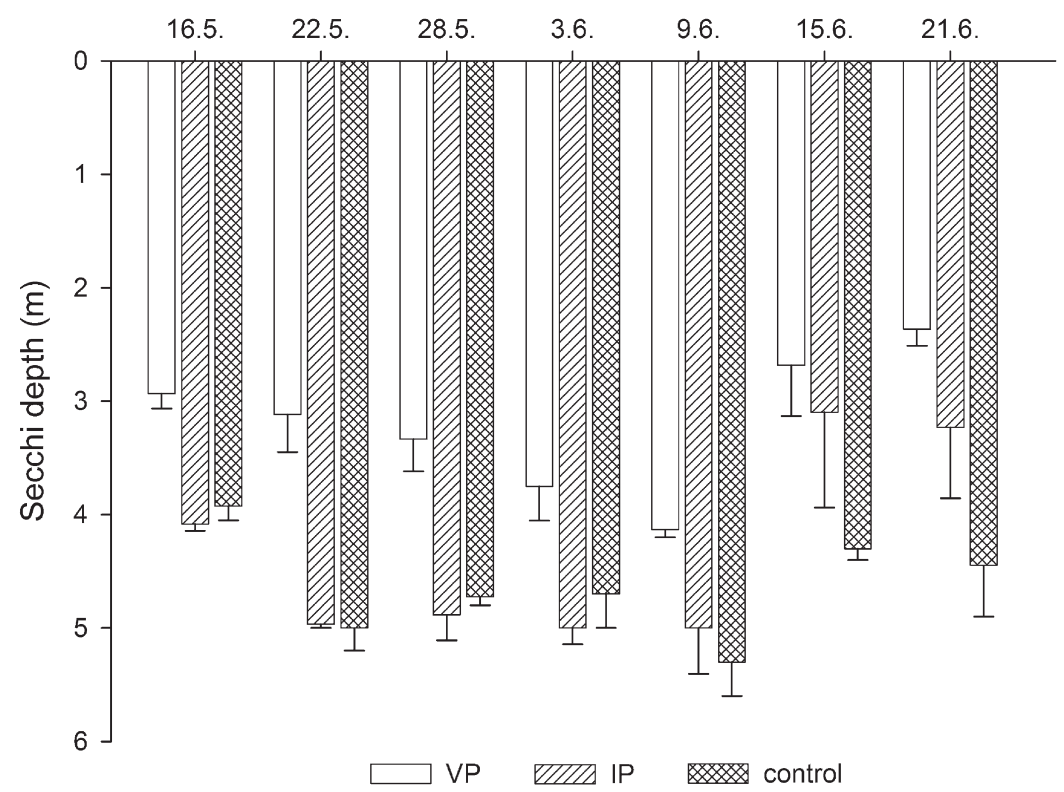

Fig. 1. Secchi depth changes (mean \pm SE) during the mesocosm experiment (blank columns $=$ VP, hatched columns $=$ IP, gridded columns $=\mathrm{NP}$ ).

At the beginning of the experiment, zooplankton abundance (mean \pm SD) was as follows: rotifers $124 \pm 56$ ind. $\mathrm{L}^{-1}$; cladocerans including Daphnia spp. $6 \pm 3$ ind. $\mathrm{L}^{-1}$ and copepod developmental stages $41 \pm 13$ ind. $\mathrm{L}^{-1}$ (both nauplii and copepodites). Abundances of $C$. vicinus and $M$. leuckarti at the beginning of the experiments were $2.3 \pm 0.6$ ind. $\mathrm{L}^{-1}$ in IP, 0 ind. $\mathrm{L}^{-1}$ in $\mathrm{VP}$ and $1.5 \pm 0.7$ ind. $\mathrm{L}^{-1}$ in the control. Adult cyclopoids in the control developed from copepodites because there were no adults added as inoculum. Ascomorpha ecaudis, Conochilus hippocrepis, Kellicottia longispina, Keratella cochlearis, Keratella quadrata and Polyarthra dolichoptera were the most abundant rotifer species. Altogether 31 rotifer species were recorded through the whole experiment. Besides the daphnids D. galeata and the larger D. pulicaria, Bosmina longirostris formed the cladoceran community at the beginning of the experiment. During the experiment, 13 other cladoceran species were recorded in the samples, most of them, such as chydorids or Diaphanosoma brachyurum, occurred only occasionally with no preferences for any particular treatment. The predatory cladoceran L. kindtii was present only a few times in low abundances in IP (the highest abundance was 4 ind. $\mathrm{L}^{-1}$ ). The regular finding of $P$. pediculus in the IP and NP treatments were highly significant in contrast with no occurrence in VP (Table 1). The only calanoid species, Eudiaptomus gracilis, regularly occurred in the Rímov reservoir and also was the important component of the zooplankton community in the experiment. Cyclops vicinus and $M$. leuckarti were the most abundant cyclopoids in all treatments, whereas Acanthocyclops trajani and Thermocyclops crassus were rarely recorded. There were no significant differences between IP and the control for either of the zooplankton taxa abundances (Table 1). However, the clear difference in proportions of cladoceran taxa showed successful manipulation $(F=17.0$; d.f. $=2 ; P<0.01)$. Similar patterns were revealed in the abundances of rotifers, cladocerans and the developmental stages of copepods in IP and the control. Cyclopoid copepod abundances increased in all treatments during the experiment (Fig. 3D and E). Similarly to the phytoplankton, zooplankton abundances varied between VP and the other treatments. Rotifers, namely A. ecaudis, K. longispina, K. cochlearis, K. quadrata and Polyarthra spp., significantly increased in abundance peaking in VP in the third week of the experiment (Fig. 3A, Table 1). The highest abundance of nauplii occurred also in VP, but peaked 1 week later (Fig. 3B). Cladoceran abundances of both predation treatments notably differed from the control where a gradual increase up to a mean density of 52 ind. $\mathrm{L}^{-1}$ was recorded. Although the initial peak with subsequent decline followed by increase occurred in IP, VP showed the opposite trend (Fig. 3C). Cladoceran abundances along with species composition considerably changed between VP and the control. Although daphnids decreased in VP, B. longirostris increase (Fig. 4). Daphnids (NP) were replaced mainly by B. longirostris (VP) whereas both large and small cladocerans coexisted in IP (Fig. 5).

\section{Fish}

With the exception of one roach, all fish were caught alive at the end of the experiment. Although there was a clear trend in increasing biomass of both perch and roach (Fig. 6), individual fish biomass did not significantly differ over time $(t=1.18 ; P=0.84$ for perch and $t=1.35$; $P=0.97$ for roach). The daily biomass accumulation of perch reached $0.04 \mathrm{~g}(0.12 \mathrm{~mm}$ in length). The growth of roach was slightly faster: $0.06 \mathrm{~g}^{\text {day }}{ }^{-1}$ corresponding to 

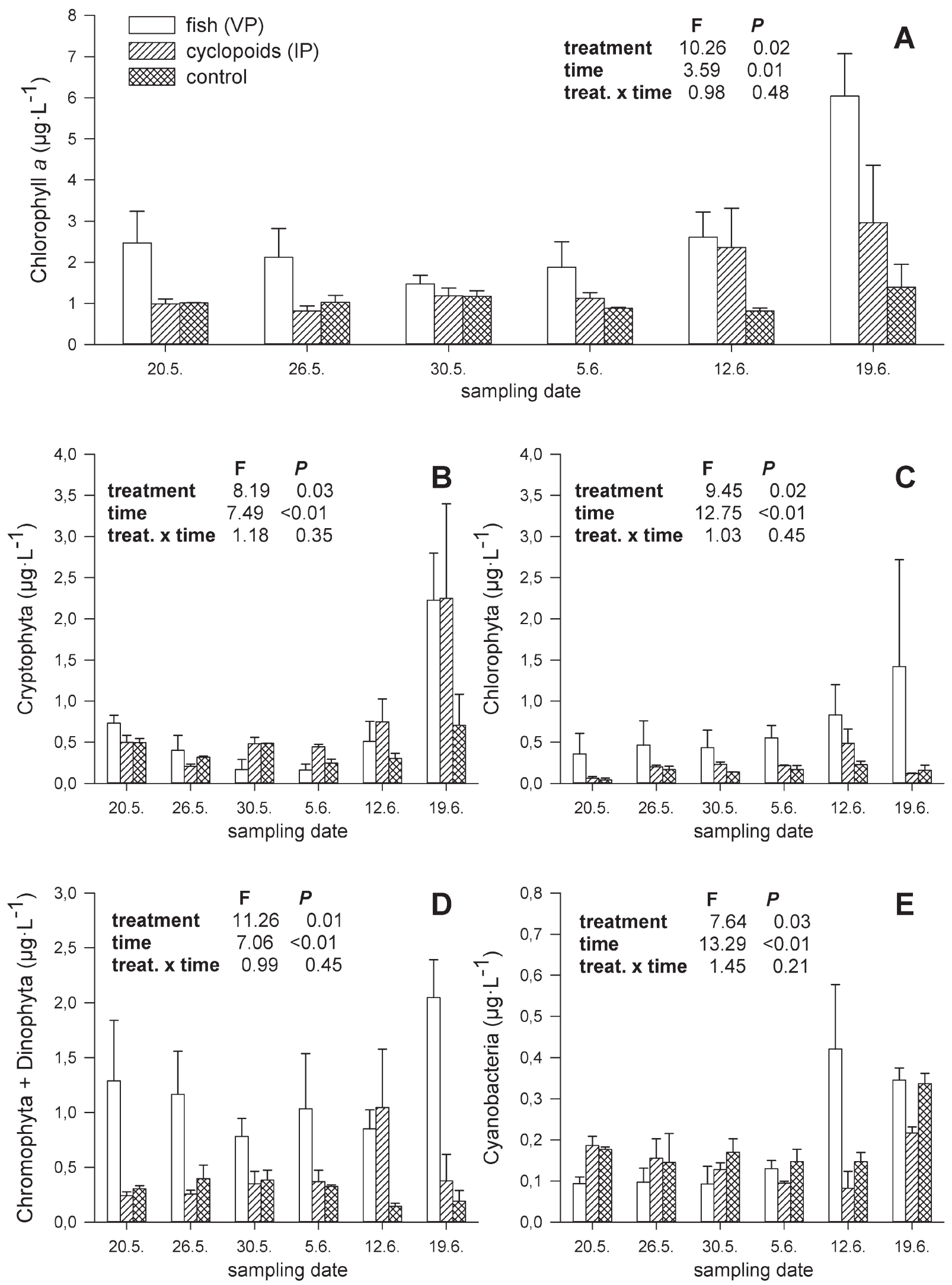

Fig. 2. Chlorophyll-a concentration (mean $\pm \mathrm{SE} ; \mu \mathrm{g} . \mathrm{L}^{-1}$ ) of the mesocosm experiment (blank columns $=\mathrm{VP}$, hatched columns $=\mathrm{IP}$, gridded columns $=\mathrm{NP}$ ). Results of one-way repeated measures ANOVA ( $F$ ratio and probability) are shown in each graph. The first graph represents the overall chlorophyll-a concentration (A) whereas the others distinguish it into cryptophytes (B), chlorophytes (C), chromophytes + dinophytes (D) and cyanobacteria (E). 
Table 1. Results of one-way repeated measures ANOVA testing the effect of treatment, time and their interaction on the abundances of rotifers, cladocerans and copepods.

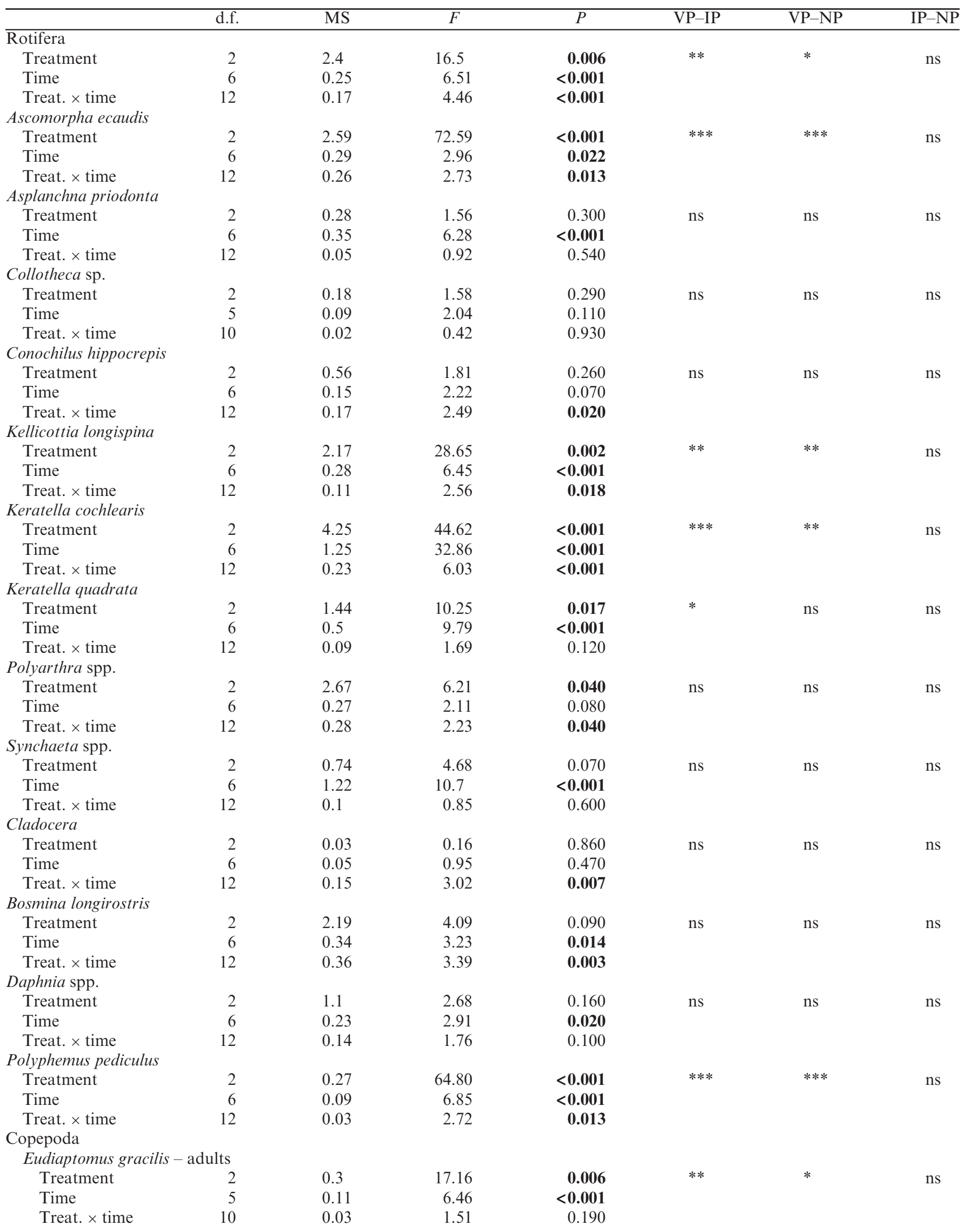


Table 1. (Contd)

\begin{tabular}{|c|c|c|c|c|c|c|c|}
\hline & d.f. & MS & $F$ & $P$ & VP-IP & $\mathrm{VP}-\mathrm{NP}$ & IP-NP \\
\hline \multicolumn{8}{|c|}{ E. gracilis - copepodites } \\
\hline Treatment & 2 & 0.03 & 1.98 & 0.230 & \multirow[t]{3}{*}{ ns } & \multirow[t]{3}{*}{ ns } & \multirow[t]{3}{*}{ ns } \\
\hline Time & 6 & 0.04 & 1.87 & 0.120 & & & \\
\hline Treat. $\times$ time & 12 & 0.04 & 2.06 & 0.054 & & & \\
\hline \multicolumn{8}{|c|}{ Cyclopidae - adults } \\
\hline Treatment & 2 & 0.11 & 0.43 & 0.670 & \multirow[t]{3}{*}{ ns } & \multirow[t]{3}{*}{ ns } & \multirow[t]{3}{*}{ ns } \\
\hline Time & 6 & 0.63 & 10.69 & $<0.001$ & & & \\
\hline Treat. $\times$ time & 12 & 0.09 & 1.58 & 0.150 & & & \\
\hline \multicolumn{8}{|c|}{ Cyclopidae - copepodites } \\
\hline Treatment & 2 & 0.05 & 0.23 & 0.800 & \multirow[t]{3}{*}{ ns } & \multirow[t]{3}{*}{ ns } & \multirow[t]{3}{*}{ ns } \\
\hline Time & 6 & 0.43 & 8.23 & $<0.001$ & & & \\
\hline Treat. $\times$ time & 12 & 0.03 & 0.53 & 0.880 & & & \\
\hline \multicolumn{8}{|l|}{ Nauplii } \\
\hline Treatment & 2 & 0.25 & 2.26 & 0.200 & \multirow[t]{3}{*}{ ns } & \multirow[t]{3}{*}{ ns } & \multirow[t]{3}{*}{ ns } \\
\hline Time & 6 & 0.15 & 1.63 & 0.170 & & & \\
\hline Treat. $\times$ time & 12 & 0.19 & 1.99 & 0.060 & & & \\
\hline
\end{tabular}

Post hoc tests showed differences between particular treatments $(\mathrm{VP}=$ vertebrate predation, $\mathrm{IP}=$ invertebrate predation and NP $=$ no predation).

Statistical significance is marked as follows: ${ }^{*} P<0.05 ; * * P<0.01 ; * * * P<0.001$; ns $=$ not significant. Significant values assuming $\alpha<0.05$ are shown in bold.

$0.14 \mathrm{~mm}$ of standard length. Total fish production during the experiment was $46 \mathrm{~kg} \cdot \mathrm{ha}^{-1}$.

\section{Discussion}

In our experiment, the cladoceran community in the fish treatment changed from dominance of large-bodied Daphnia spp. at the beginning of the experiment to dominance of the small B. longirostris at the end (Figs. 4 and 5). Our results clearly confirm the hypothesis that feeding by planktivorous fish leads to a marked suppression of large-bodied cladocerans. As a consequence of the apparent lower grazing pressure, chlorophyll-a concentration and rotifer abundances increased in the absence of daphnids ( $c f$. Figs. 2 and 5). Rotifers and small-bodied cladocerans were repeatedly shown to exhibit lower grazing pressure on phytoplankton (Table 2). On the other hand, our results do not support the hypothesis that rotifers and small cladocerans are predominantly affected by cyclopoid predation (in terms of abundances). Cyclopoid copepods usually prefer smaller prey (Brandl, 2005) which corresponds to higher proportion of the large-bodied daphnids in IP treatment and the control. In general, no significant differences were observed between the IP treatment and the control, which showed similar trends during the whole experiment.

A decline in Daphnia spp. populations often correlates with the development of fish, especially the $0+$ classes. Vertebrate predation, represented mostly by fish, is commonly considered as the essential factor affecting planktonic communities at lower trophic levels. Ha et al. (2013) provided successful biomanipulation on the lake with maximum depth of $9.1 \mathrm{~m}$ and showed an increase in transparency from 2-4 $\mathrm{m}$ due to the enhanced grazing of D. galeata when planktivorous fish were eliminated.
The manipulative experiment in this study was performed using juvenile perch (P. fluviatilis L.) and roach (R. rutilus (L.)) as the fish predators. Both species are a regular component of fish assemblages in European meso- and eutrophic water bodies (Persson et al., 1991). The VP treatment, stocked with yearling fish, combined the almost exclusive feeding on herbivore zooplankton by roach with the broader perch diet also consisting of copepods. D. galeata has been shown to contribute almost $100 \%$ to the diet composition of roach in the Rímov reservoir in May (Vašek and Kubečka, 2004). In contrast, copepods comprise one half of the perch diet in the Rímov reservoir in spring (Peterka and Matěna, 2009). It has been suggested that a lack of extensive littoral habitats along with the occurrence of regular oxygen deficiency in deeper strata limits the area of fish feeding to the epilimnion where an abundant zooplankton community is available (Kubečka et al., 1998; Vašek et al., 2006). Our experimental fish stock was higher in comparison with the current estimation of the reservoir fish biomass but did not exceed biomass in the past years. Kubečka (1989) reported the total biomass of roach, perch and bream to be almost $900 \mathrm{~kg} \cdot \mathrm{ha}^{-1}$ in 1982. Based on horizontal acoustics data, the average total fish biomass in 2004 was $216.3 \mathrm{~kg}$.ha ${ }^{-1}$ ranging from ca $700 \mathrm{~kg} \cdot \mathrm{ha}^{-1}$ in the tributary zone to $200 \mathrm{~kg} . \mathrm{ha}^{-1}$ at the dam (Draštík et al., 2008).

Both perch and roach were often used as the fish predator in mesocosm studies in the past. We summarised selected results regarding mesocosms stocked with perch and roach (Table 2). With only one exception (Kurmayer and Wanzenböck, 1996), daphnids were always eliminated and in turn phytoplankton increased in biomass. Consequently, Secchi depth decreased regardless of fish abundance. In general, similar experiments yielded similar results as documented in our study which stressed the impact of more complex fish assemblages. However, clear 

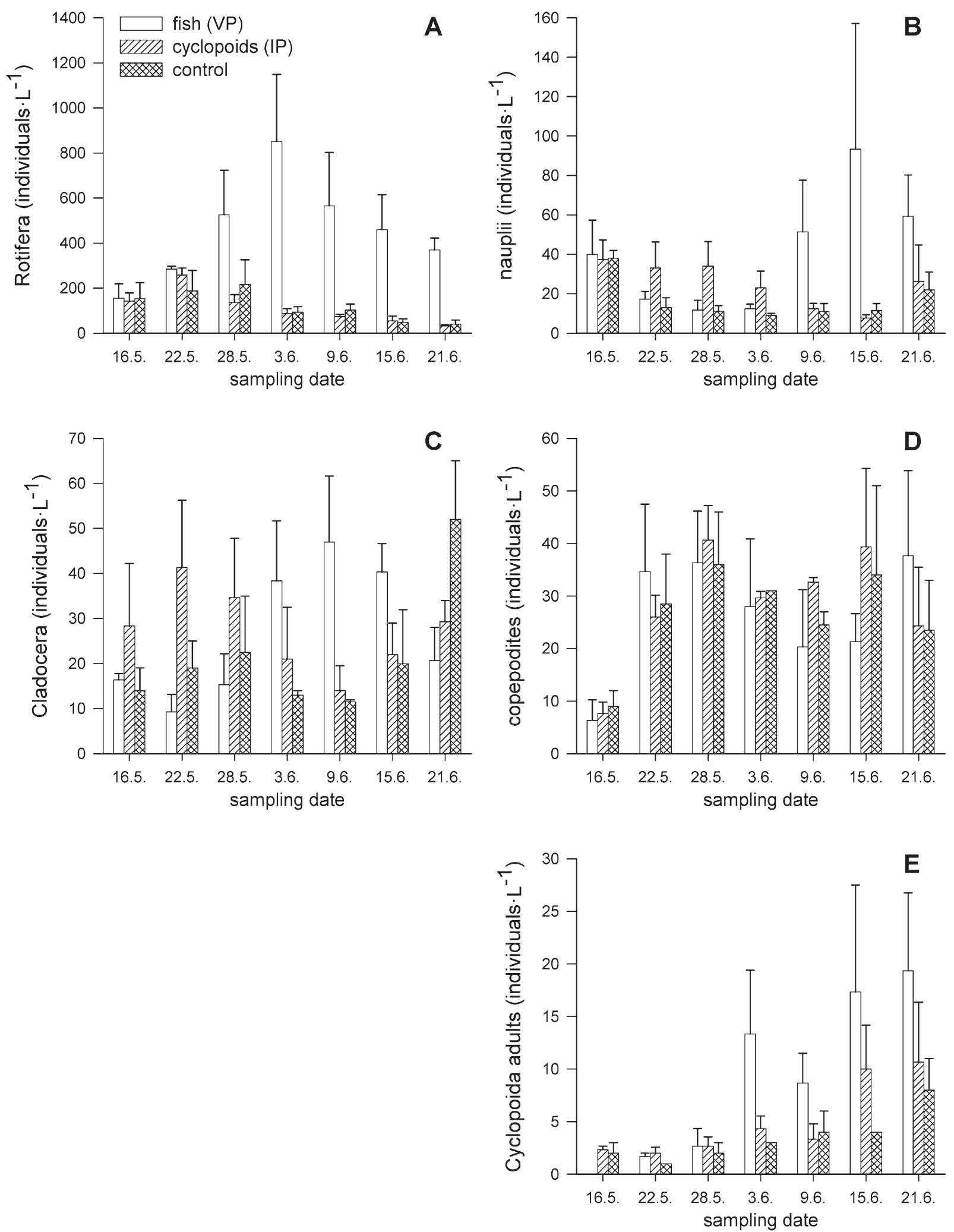

Fig. 3. Zooplankton abundances (mean $\pm \mathrm{SE}$; ind. $\mathrm{L}^{-1}$ ) of the mesocosm experiment (blank columns $=\mathrm{VP}$, hatched columns $=\mathrm{IP}$, gridded columns $=\mathrm{NP}$; the legend in panel A is valid for all the panels). Five groups of zooplankton were taken into account: rotifers (A), nauplii (B), cladocerans (C), copepodites (D) and adult cyclopoids (E). 

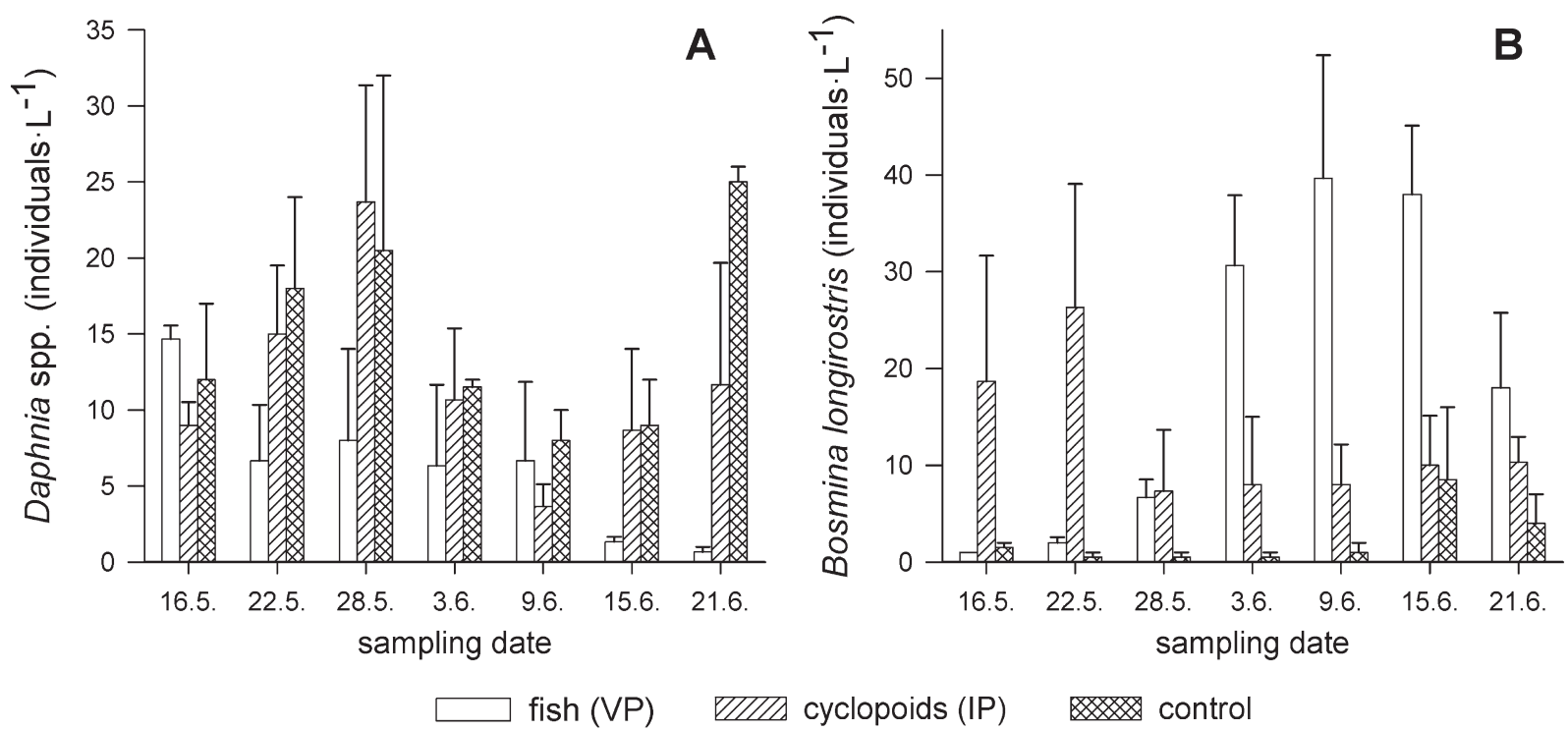

Fig. 4. The changes of cladoceran abundances (mean $\pm \mathrm{SE}$; ind. $\mathrm{L}^{-1}$ ) during the course of the experiment (blank columns $=\mathrm{VP}$, hatched columns $=\mathrm{IP}$, gridded columns $=\mathrm{NP}$ ). Left panel $(\mathrm{A})$ : Daphnia spp. abundance; right panel (B): B. longirostris abundance.

evidence that fish feeding regulates zooplankton seasonal community dynamics is still missing (Mehner and Thiel, 1999).

Recently, Nicolle et al. (2011) reported suppression of cladocerans by juvenile roach regardless of resource availability. Cladoceran decline was not so prominent in treatments with low fish densities and high resource availability at the same time. Such an effect can be possible due to an increase in population growth through changes in reproductive parameters of particular zooplankton taxa. Besides lesser clutch sizes and/or shorter development time, cladocerans reach maturity earlier and the body size of primiparae is smaller. Macháček and Sed'a (1998) revealed a similar pattern in the Rímov reservoir where smaller Daphnia body sizes were found in the more eutrophic tributary zone compared to the dam. Since the tributary phytoplankton biomass is usually much higher than near to the dam, Vašek et al. (2003) also concluded that decreased daphnid length is probably related to fish predation pressure.

Although $D$. galeata forms the distinct hypolimnetic subpopulation in the Rímov reservoir, the majority of daphnid population inhabits the upper part of epilimnion $(0-4 \mathrm{~m})$. Horizontal migration was not observed (Sed'a et al., 2007). The depth limitation of our mesocosm design $(9.5 \mathrm{~m})$ was therefore not a constraint on using a deep water refuge.

Total daily consumption by pelagic underyearling fish in the dam part of the Rímov reservoir in 2006 and 2007 did not exceed $0.3 \%$ of the total biomass of D. galeata during the May-July period (Vašek, unpublished data), which indicates a rather low impact of underyearling fish on spring-early summer daphnid dynamics. These results contrast to the significant daphnid decline in the VP mesocosms, which was apparently caused by a higher abundance of juvenile fish compared to the reservoir or possibly by some artificial interactions between zooplankton and fish derived from the enclosed assemblages.

In spite of the substantial effect of fish stock on zooplankton, a relatively high importance of direct predation by planktonic IP was also reported (e.g., Chang and Hanazato, 2005; Wojtal et al., 2007; Manca et al., 2008). Cyclopoid copepods, mainly C. vicinus and M. leuckarti, represented the planktonic IP in our mesocosms. Although later copepodites and adults of both species are carnivorous, $C$. vicinus is able to survive and develop to adult stage on an algal diet whereas $M$. leuckarti requires rotifers as part of their diet (Brandl, 2005). Predation rates of $C$. vicinus on rotifers varied during springtime up to a maximum of 11.3 rotifers per day in the Řimov reservoir in April (Devetter and Sed'a, 2006). Nevertheless, $C$. vicinus is able to reduce $D$. galeata population density by its predation on the juvenile Daphnia, as shown in the Rímov reservoir by Brandl (1998). Cyclops predation also showed a great selectivity and, therefore, it is reasonable to assume a different species-specific impact. The rotifer species Synchaeta lackowitziana, Polyarthra spp. and $K$. cochlearis were positively selected in contrast to $K$. longispina, which bears long spines (Devetter and Sed'a, 2006). Brandl (2005) estimated the predation rates of $C$. vicinus as from 0.3 to 43 rotifers per cyclopoid per day. $M$. leuckarti seemed to be even more carnivorous than $C$. vicinus because it requires a rotifer diet to produce eggs (Brandl, 2005). Wojtal et al. (2004) found an important role of predatory cladocerans over juvenile fish in the decline of daphnid density. Gliwicz et al. (1978) reported L. kindtii and cyclopoid copepods (mainly M. leuckarti) to be responsible for elimination of zooplankton biomass. There are no IP such as Chaoborus larvae or Bythotrephes in the Ŕímov reservoir. Predatory cladocerans were represented only by 

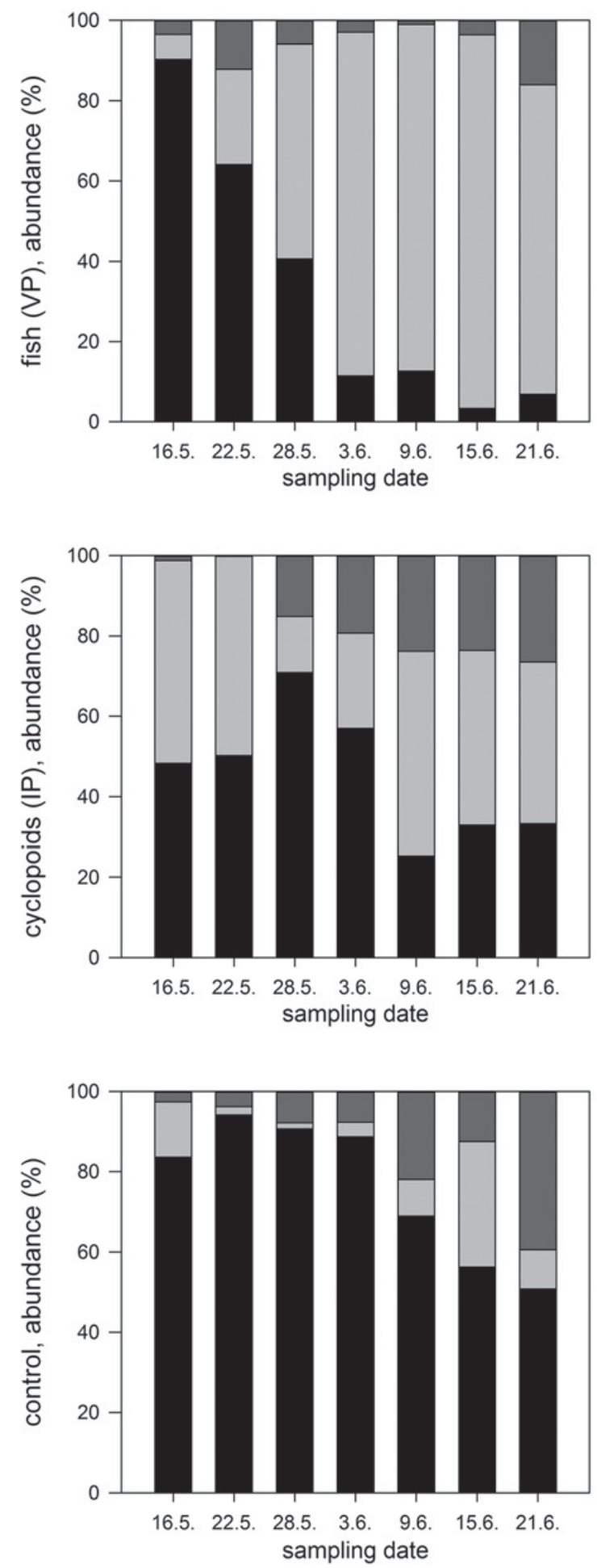

Daphnia spp.

B. longirostris

others

Fig. 5. The proportion of cladoceran taxa groups in every treatment (VP, IP and NP) over the course of the experiment. Cladocerans were divided into the following groups: Daphnia spp., B. longirostris and other taxa, including Leptodora and Polyphemus.
$P$. pediculus, which flourished in the IP and control treatments (Table 1). Although $P$. pediculus typically inhabits littoral zones, its occurrence in pelagic mesocosms implicated its origin from the plankton community used to inoculate the mesocosms at the beginning. Contrary to cyclopoid copepods, the predatory strategy of $P$. pediculus includes visual contact followed by chasing and attack if the prey size is assessed as optimal, not too small but not too large either (Young and Taylor, 1988).

The simple direct reduction of large-bodied zooplankton by planktivorous fish is not probably the only mechanism of their decline. Hülsmann and Mehner (1997) found a higher proportion of adult daphnids in control treatments than in their treatment comparable with our VP. They concluded that the lack of larger size classes may lead to a decline of $D$. galeata due to selective feeding by fish together with insufficient food quality. Daphnids are not entirely eliminated by direct feeding, but low reproduction in low resource availability caused the reduction anyway. However, in the VP treatment, cryptophytes and chlorophytes dominated the phytoplankton and are considered to be a suitable food source for zooplankton (Reynolds, 2006). Thus, food availability was likely not the limiting factor. Although we did not present zooplankton body sizes, we also observed a higher percentage of juveniles over adult daphnids in VP. Finally, non-direct effects such as nutrient recycling by fish may greatly influence phytoplankton growth and consequently the structure and abundance of the zooplankton community (Vanni and Layne, 1997). The increase in a mixed group of chromophytes and dinophytes (Fig. 2D) at the end of the experiment was likely associated with the development of the early summer population of the diatom Fragilaria crotonensis, which recurrently dominates the summer phytoplankton along with filamentous and colonial cyanobacteria (Znachor et al., 2008).

The Norwegian mesotrophic Lake Gjersjøen (Brabrand et al., 1986) illustrates nicely the complexity of interactions between fish and cyclopoid predators. The roach population in that lake fed on both daphnids and cyclopoids. The absence of roach predation allowed an increase in the cyclopoid population which effectively controlled daphnids. Phytoplankton biomass remained high in both cases. A similar situation was found in Lake Kinneret where the reduction in Kinneret bleak (Acanthobrama terraesanctae) increased the abundances of cyclopoid copepods. Cyclopoid predation on herbivorous zooplankton subsequently increased the phytoplankton biomass (Blumenshine and Hambright, 2003).

This experiment showed a strong effect of large-bodied cladocerans in decreasing chlorophyll-a concentration in the absence of fish. Therefore, a strong effect of fish over cyclopoid predation was supported. Since cladoceran size structure should be responsible for the different efficiencies in phytoplankton elimination, switching from daphnids to bosminids or altering body size in Daphnia spp. could increase phytoplankton abundances. 


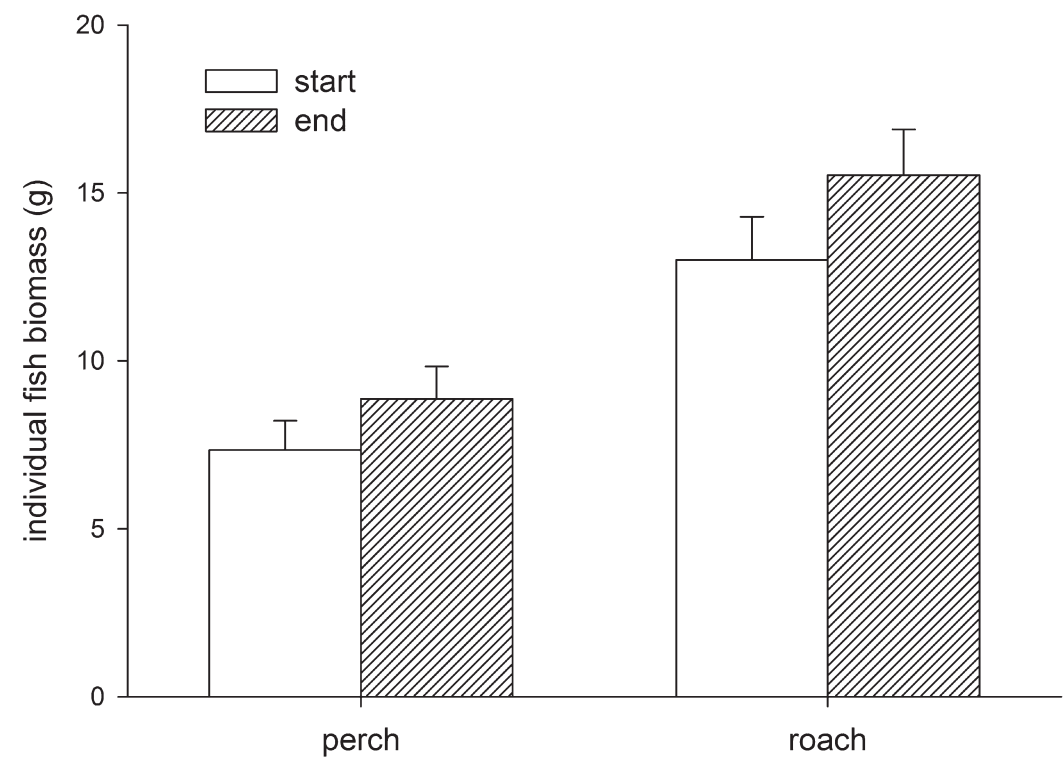

Fig. 6. Fish biomass (mean \pm SE) at the beginning (blank columns) and end (hatched columns) of the experiment. Neither perch nor roach biomasses were significantly higher at the end.

Table 2. Summary of the selected experimental studies using roach (Rutilus rutilus) or perch (Perca fluviatilis or P. flavescens) as the top predator of the zooplankton community.

\begin{tabular}{|c|c|c|c|c|c|c|c|c|c|}
\hline $\begin{array}{l}\text { Fish } \\
\text { class }\end{array}$ & $\begin{array}{l}\text { Abundance } \\
\left(\text { ind. } \mathrm{m}^{3} \text { ) }\right.\end{array}$ & Phytoplankton & Rotifera & Daphnia & Bosmina & Secchi & $\begin{array}{c}\text { Volume } \\
\left(\mathrm{m}^{3}\right)\end{array}$ & $\begin{array}{c}\text { Duration } \\
\text { weeks }\end{array}$ & References \\
\hline$\overline{P e r c h ~ a n d ~ r o a c h}$ & & & & & & & & & \\
\hline $\begin{array}{l}1+ \\
\text { Perch }\end{array}$ & 0.3 & + & + & - & + & - & 13 & 5 & Present study \\
\hline $0+$ & 0.3 & + & & - & + & - & 750 & 16 & (Post and McQueen, 1987) \\
\hline $0+$ & 0.8 & + & & - & + & - & 750 & 16 & (Post and McQueen, 1987) \\
\hline $0+$ & 1.9 & + & + & - & - & - & 9.5 & 6.7 & (Bertolo et al., 2000) \\
\hline $0+$ & 2 & + & & - & & - & 40 & 10.9 & $\begin{array}{l}\text { (Kurmayer and } \\
\text { Wanzenböck, 1996) }\end{array}$ \\
\hline $\begin{array}{l}>1+ \\
\text { Roach }\end{array}$ & 0.1 & & & - & - & + & 9.5 & 6.7 & (Bertolo et al., 2000) \\
\hline $0+$ & 2 & + & & + & & - & 40 & 10.9 & $\begin{array}{l}\text { (Kurmayer and } \\
\text { Wanzenböck, 1996) }\end{array}$ \\
\hline $0+$ & $12.5-105$ & + & & - & - & & 0.4 & 6 & (Nicolle et al., 2011) \\
\hline $1+$ & $3-4$ & + & + & - & + & & ca 1 & 5.6 & (Hansson et al., 2004) \\
\hline $1+$ & 10 & + & + & & & & 0.3 & 1.6 & (Ślusarczyk, 1997) \\
\hline $1+$ & $13-21$ & + & + & - & - & & ca 1 & 5.6 & (Hansson et al., 2004) \\
\hline $2+$ & $0.4-0.5$ & & + & - & - & & 7 & 4 & (Hessen, 1985) \\
\hline
\end{tabular}

The selection of published papers was based mainly on the amount of available variables which can be compared. The impact on phytoplankton, rotifers, Daphnia and Bosmina, and water transparency is marked with " + " for increase in abundances or " - " for a decreasing trend.

Acknowledgements. We are grateful to the Institute of Hydrobiology (Biology Centre AS CR, České Budějovice) for use of their field facilities and back areas. The River Authority of Povodí Vltavy, s.p. allowed access to the reservoir. We also would like to thank Pavel Rychtecký who assisted with the phytoplankton survey and Katka Zadinová who helped with the preparation of the experiment and regular sampling. The comments of two anonymous reviewers improve the overall quality of the manuscript. Keith Edwards kindly corrected and improved the English of the manuscript. This study was supported by the Grant Agency of the University of South Bohemia (24/2007/P-PrF, 04-142/2010/P and 04/145/2013/P) and is submitted as a part of the PhD thesis of Michal Sorf.

\section{References}

Beklioglu M., 1999. A review on the control of eutrophication in deep and shallow lakes. Turk. J. Zool., 23, 327-336.

Benndorf J., Wissel B., Sell A.F., Hornig U., Ritter P. and Böing W., 2000. Food web manipulation by extreme enhancement of piscivory: an invertebrate predator compensates for the effects of planktivorous fish on a plankton community. Limnologica, 30, 235-245.

Berg S., Jeppesen E. and Søndergaard M., 1997. Pike (Esox lucius L.) stocking as a biomanipulation tool 1. Effects on the fish population in Lake Lyng, Denmark. Hydrobiologia, 342-343, 311-318. 
Bertolo A., Lacroix G., Lescher-Moutoue F. and CardinalLegrand C., 2000. Plankton dynamics in planktivore- and piscivore- dominated mesocosms. Arch. Hydrobiol., 147, 327-349.

Beutler M., Wiltshire K.H., Meyer B., Moldaenke C., Luring C., Meyerhofer M., Hansen U.P. and Dau H., 2002. Afluorometric method for the differentiation of algal populations in vivo and in situ. Photosynth. Res., 72, 39-53.

Blumenshine S.C. and Hambright H.D., 2003. Top-down control in pelagic systems: a role for invertebrate predation. Hydrobiologia, 491, 347-356.

Brabrand A., Faafeng B. and Nilssen J.P.M., 1986. Juvenile roach and invertebrate predators: delaying the recovery phase of eutrophic lakes by suppression of efficient filterfeeders. J. Fish Biol., 29, 99-106.

Brandl Z., 1998. Life strategy and feeding relations of Cyclops vicinus in two reservoirs. Int. Rev. Hydrobiol., 83, 381-388.

Brandl Z., 2005. Freshwater copepods and rotifers: predators and their prey. Hydrobiologia, 546, 475-489.

Brett M.T. and Goldman C.R., 1996. A meta-analysis of the freshwater trophic cascade. Proc. Natl. Acad. Sci. USA, 93, $7723-7726$.

Brooks J.L. and Dodson S.I., 1965. Predation, body size, and composition of plankton. Science, 150, 28-35.

Carpenter S.R. and Kitchell J.F., 1992. Trophic cascade and biomanipulation: interface of research and management - a reply to the comment by DeMelo et al. Limnol. Oceanogr., 37, 208-213.

Carpenter S.R., Kitchell J.F. and Hodgson J.R., 1985. Cascading trophic interactions and lake productivity. BioScience, 35, 634-639.

Chang K.H. and Hanazato T., 2005. Impact of selective predation by Mesocyclops pehpeiensis on a zooplankton community: experimental analysis using mesocosms. Ecol. Res., 20, 726-732.

Devetter M. and Seda J., 2006. Regulation of rotifer community by predation of Cyclops vicinus (Copepoda) in the Rímov Reservoir in spring. Int. Rev. Hydrobiol., 91, 101-112.

Draštík V., Kubečka J., Tušer M., Čech M., Frouzová J., Jarolím O. and Prchalová M., 2008. The effect of hydropower on fish stocks: comparison between cascade and non-cascade reservoirs. Hydrobiologia, 609, 25-36.

Dussart B.H. and Defaye D., 2001. Copepoda. Introduction to the Copepoda, Backhuys Publishers, Leiden, 344 p.

Edmonson W.T., 1971. Methods for processing samples and developing data. In: Edmonson W.T. (ed.), A Manual on Methods for the Assessment of Secondary Productivity in Fresh Waters, IPB Handbook, Vol. 17, Blackwell Scientific Publications, Oxford, 127-137.

Gliwicz Z.M., Hillbricht-Ilkowska A. and Wegleńska T., 1978. Contribution of fish and invertebrate predation to the elimination of zooplankton biomass in two Polish lakes. Verh. Internat. Verein. Limnol., 20, 1007-1011.

Ha J.-Y., Saneyoshi M., Park H.-D., Toda H., Kitano S., Homma T., Shiina T., Moriyama Y., Chang K.-H. and Hanazato T., 2013. Lake restoration by biomanipulation using piscivore and Daphnia stocking; results of the biomanipulation in Japan. Limnology, 14, 19-30.

Hansson L.-A. and Tranvik L.J., 1996. Quantification of invertebrate predation and herbivory in food chains of low complexity. Oecologia, 108, 542-551.
Hansson L.-A., Annadotter H., Bergman E., Hamrin S.F., Jeppesen E., Kairesalo T., Luokkanen E., Nilsson P.-Åk., Søndergaard M. and Strand J., 1998. Biomanipulation as an application of food-chain theory: constraints, synthesis, and recommendations for temperate lakes. Ecosystems, 1, $558-574$.

Hansson L.-A., Gyllström M., Stahl-Delbanco A. and Svensson M., 2004. Responses to fish predation and nutrients by plankton at different levels of taxonomic resolution. Freshwater Biol., 49, 1538-1550.

Hessen D.O., 1985. Selective zooplankton predation by preadult roach (Rutilus rutilus): the size-selective hypothesis versus the visibility-selective hypothesis. Hydrobiologia, 124, 73-79.

Horppila J. and Liljendahl-Nurminen A., 2005. Clay-turbid interactions may not cascade - a reminder for lake managers. Restor. Ecol., 13, 242-246.

Hrbáček J., 1962. Species composition and the amount of the zooplankton in relation to the fish stock. Rozpravy Československé akademie véd. Matematické a prírodní vědy, $72,1-116$.

Hrbáček J. and Hrbáčková-Esslová M., 1960. Fish stock as a protective agent in the occurrence of slow-developing dwarf species and strains of the genus Daphnia. Int. Rev. Gesamten Hydrobiol., 45, 355-358.

Hrbáček J., Dvořáková M., Kořínek V. and Procházková L., 1961. Demonstration of the effect of the fish stock on the species composition of zooplankton and the intensity of metabolism of the whole plankton association. Verh. Internat. Verein. Limnol., 14, 192-195.

Hrbáčková M., 1974. The size of primipae and neonates of Daphnia hyalina Leydig (Crustacea, Cladocera) under natural and enriched food conditions. Věstnik Čskoslovenské společnosti zoologické, 38, 98-105.

Hülsmann S. and Mehner T., 1997. Predation by underyearling perch (Perca fluviatilis) on a Daphnia galeata population in a short-term enclosure experiment. Freshwater Biol., 38, 209-219.

Jeffries M., 1988. Individual vulnerability to predation: the effect of alternative prey types. Freshwater Biol., 19, 49-56.

Kolar C.S. and Wahl D.H., 1998. Daphnid morphology deters fish predators. Oecologia, 116, 556-564.

Kubečka J., 1989. Development of the ichtyofauna of the Rímov Reservoir and its management. Arch. Hydrobiol. Beih. Ergebn. Limnol., 33, 611-613.

Kubečka J., Sed'a J. and Matěna J., 1998. Fish-zooplankton interactions during spring in a deep reservoir. Int. Rev. Hydrobiol., 83, 431-442.

Kurmayer R. and Wanzenböck J., 1996. Top-down effects of underyearling fish on a phytoplankton community. Freshwater Biol., 36, 599-609.

Macháček J. and Sed'a J., 1998. Spatio-temporal changes of morphological and life-history parameters in Daphnia galeata in a canyon-shaped dam lake. Int. Rev. Hydrobiol., 83, 171-178.

Manca M., Vijverberg J., Polishchuk L.V. and Voronov D.A., 2008. Daphnia body size and population dynamics under predation by invertebrate and fish predators in Lago Maggiore: an approach based on contribution analysis. J. Limnol., 67, 15-21.

Mehner T. and Thiel R., 1999. A review of predation impact by $0+$ fish on zooplankton in fresh and brackish waters 
of the temperate northern hemisphere. Environ. Biol. Fish., $56,169-181$.

Nicolle A., Hansson L.-A., Brodersen J., Nilsson P.A. and Brönmark C., 2011. Interactions between predation and resources shape zooplankton population dynamics. PLoS ONE, 6, e16534.

Persson L. and Greenberg L.A., 1990. Optimal foraging and habitat shift in perch (Perca fluviatilis) in a resource gradient. Ecology, 71, 1699-1713.

Persson L., Diehl S., Johansson L., Andersson G. and Hamrin S.F., 1991. Shifts in fish communities along the productivity gradient of temperate lakes - patterns and the importance of size-structured interactions. J. Fish Biol., 38, 281-293.

Peterka J. and Matěna J., 2009. Differences in feeding selectivity and efficiency between young-of-the-year European perch (Perca fluviatilis) and roach (Rutilus rutilus) - field observations and laboratory experiments on the importance of prey movement apparency vs. evasiveness. Biologia, 64, 786-794.

Post J.R. and McQueen D.J., 1987. The impact of planktivorous fish on the structure of a plankton community. Freshwater Biol., 17, 79-89.

Reynolds C.S., 2006. The Ecology of Phytoplankton, Cambridge University Press, Cambridge, $535 \mathrm{p}$.

Sed'a M., Kolářová K., Petrusek A. and Macháček J., 2007. Daphnia galeata in the deep hypolimnion: spatial differentiation of a "typical epilimnetic" species. Hydrobiologia, 594, $47-57$.

Ślusarczyk M., 1997. Impact of fish predation on a smallbodied cladoceran: limitation or stimulation? Hydrobiologia, 342-343, 215-221.

Šorf M., Brandl Z., Znachor P. and Vašek M., 2013. Floating large-volume mesocosms as a simple, low-cost experimental design suitable for the variety of lakes and reservoirs. Fundam. Appl. Limnol., 183, 41-48.

Straile D. and Halbich A., 2000. Life history and multiple antipredator defenses of an invertebrate pelagic predator, Bythotrephes longimanus. Ecology, 81, 150-163.
Straškraba M., 1964. Preliminary results of a new method for the quantitative sorting of freshwater net plankton into main groups. Limnol. Oceanogr., 9, 268-270.

Vanni M.J. and Layne C.D., 1997. Nutrient recycling and herbivory as mechanisms in the "top-down" effect of fish on algae in lakes. Ecology, 78, 21-40.

Vašek M. and Kubečka J., 2004. In situ diel patterns of zooplankton consumption by subadult/adult roach Rutilus rutilus, bream Abramis brama, and bleak Alburnus alburnus. Folia Zool., 53, 203-214.

Vašek M., Kubečka J. and Sed'a J., 2003. Cyprinid predation on zooplankton along the longitudinal profile of a canyonshaped reservoir. Arch. Hydrobiol., 156, 535-550.

Vašek M., Kubečka J., Matěna J. and Seďa J., 2006. Distribution and diet of $0+$ fish within a canyon-shaped European reservoir in late summer. Int. Rev. Hydrobiol., 91, 178-194.

Wallace R. L., Snell T. W., Ricci C. and Nogrady T., 2006. Rotifera. Volume 1: Biology, Ecology and Systematics., Backhuys Publishers and Kenobi Publishers.

Werner E.E. and Hall D.J., 1974. Optimal foraging and the size selection of prey by the bluegill sunfish (Lepomis macrochirus). Ecology, 55, 1042-1052.

Wojtal A., Frankiewicz P., Wagner-Lotkowska I. and Zalewski M., 2004. The evaluation of the role of pelagic invertebrate versus vertebrate predators on the seasonal dynamics of filtering Cladocera in a shallow, eutrophic reservoir. Hydrobiologia, 515, 123-135.

Wojtal A., Frankiewicz P., Andziak M. and Zalewski M., 2007. The influence of invertebrate predators on Daphnia spatial distribution and survival in laboratory experiments: support for Daphnia horizontal migration in shallow lakes. Int. Rev. Hydrobiol., 92, 23-32.

Young S. and Taylor V.A., 1998. Visually guided chases in Polyphemus pediculus. J. Exp. Biol., 137, 387-398.

Znachor P., Zapomělová E., Řeháková K., Nedoma J. and Šimek K., 2008. The effect of extreme rainfall on summer succession and vertical distribution of phytoplankton in a lacustrine part of a eutrophic reservoir. Aquat. Sci., $70,77-86$. 